\title{
Normalizacja przetworów naftowych i biopaliw płynnych w latach 2014-2018
}

\begin{abstract}
W artykule przedstawiono podstawowe informacje dotyczące normalizacji przetworów naftowych i biopaliw w Polsce w powiązaniu z normalizacją międzynarodową i europejską. Omówiono główne zasady uczestnictwa krajowej jednostki normalizacyjnej, jaką w Polsce jest Polski Komitet Normalizacyjny (PKN), w pracach normalizacyjnych Europejskiego Komitetu Normalizacyjnego (CEN) i Międzynarodowej Organizacji Normalizacyjnej (ISO). Przedstawiono organy techniczne krajowej jednostki normalizacyjnej, w których zakresie tematycznym znajduje się normalizacja przetworów naftowych: Komitet Techniczny 222 ds. Przetworów Naftowych i Cieczy Eksploatacyjnych oraz Podkomitet KT 222/PK 1 ds. Paliw Płynnych, Podkomitet KT 222/PK 2 ds. Asfaltów, Podkomitet KT 222/PK 3 ds. Olejów Smarowych, funkcjonujące zgodnie z wprowadzonymi w 2012 roku zmianami w procedurach PKN. Przedstawiono ogólne informacje dotyczące prac grup roboczych (WG) działających w komitetach technicznych CEN/TC, do których jako eksperci delegowani są, między innymi, specjaliści Instytutu Nafty i Gazu - Państwowego Instytutu Badawczego (INiG - PIB), funkcjonujących w ramach komitetu technicznego CEN/TC 19 Gaseous and liquid fuels, lubricants and related products of petroleum, synthetic and biological origin: CEN/TC 19/WG 9 Chromatographic test method, CEN/TC 19/WG 21 Specification for unleaded petrol, CEN/TC 19/WG 23 Specification of automotive LPG and related test method, CEN/TC 19/WG 24 Specification of distillate fuels, CEN/TC 19/WG 27 Elemental analysis of petroleum and related products. Podano również informacje dotyczące Komitetu Technicznego PKN KT 144 ds. Koksu i Przetworzonych Paliw Stałych, działającego w obszarze tematyki CEN/TC 383 Sustainably produced biomass for energy applications i grupy roboczej CEN/TC 383/WG 3 Biodiversity and environmental aspects, oraz KT 319 ds. Produktów Biobazowych, obejmującego tematykę CEN/TC 411 Bio-based products.
\end{abstract}

Słowa kluczowe: normalizacja, przetwory naftowe, paliwa i biopaliwa płynne, asfalty, środki smarowe.

\section{Standardization of petroleum products and liquid biofuels in the years 2014-2018}

The article presents basic information on the standardization of petroleum products and biofuels in Poland, in connection with International and European Standardization. Basic rules for the participation of the national standardization body in Poland, which is the Polish Committee for Standardization of PKN in the standardization work of the European Committee for Standardization (CEN) and the International Standardization Organization (ISO) were discussed. The technical bodies of the PKN were presented, the scope of which is the standardization of petroleum products: Technical Committee KT 222 for Petroleum Products and Sub-committee's of KT 222: Sub-committee KT 222/PK 1 for Liquid Fuels, Sub-committee KT 222/PK 2 for Bitumen, Sub-committee KT 222/PK 3 for Lubricating, operating in accordance with the changes introduced in 2012 in PKN's procedures. General information on the activities of the working groups (WG) operating in CEN/TC technical committees, to which specialists of INiG - PIB, are delegated as the experts, operating within the technical committee CEN/TC 19 Gaseous and liquid fuels, lubricants and related products of petroleum, synthetic and biological origin: CEN/TC 19/WG 9 Chromatographic test method, CEN/TC 19/WG 21 Specification for unleaded petrol, CEN/TC 19/WG 23 Specification of automotive LPG and related test method, CEN/TC 19/WG 24 Specification of distillate fuels, CEN/TC 19/WG 27 Elemental analysis of petroleum and related products. Information on Technical Committee KT 144 for Coke and Processed Solid Fuels, operating in the area of CEN/TC 383 Sustainably produced biomass for energy applications and CEN/TC 383/WG 3 Biodiversity and environmental aspects, as well as KT 319 for Biobase Products covering CEN/TC 411 Bio-based products is also provided.

Key words: standardization, petroleum products, liquid fuels and biofuels, bitumen, lubricants. 


\section{Wprowadzenie}

W Polskim Komitecie Normalizacyjnym (PKN) tematyka obejmująca przetwory naftowe i ciecze eksploatacyjne oraz biopaliwa płynne umiejscowiona jest w Sektorze Chemii (SCH) w Komitecie Technicznym 222 ds. Przetworów Naftowych i Cieczy Eksploatacyjnych, odpowiednio w trzech podkomitetach tego komitetu technicznego. Zakres tematyczny działania poszczególnych podkomitetów KT 222 obejmuje:

- KT 222/PK 1 ds. Paliw Płynnych - paliwa płynne pochodzenia naftowego, produkty podobne pochodzenia syntetycznego i biologicznego,

- KT 222/PK 2 ds. Asfaltów - asfalty drogowe, asfalty przemysłowe, emulsje asfaltowe,

- KT 222/PK 3 ds. Olejów Smarowych - oleje smarowe i specjalne środki smarowe pochodzenia naftowego, produkty podobne pochodzenia syntetycznego i biologicznego [4].

Sekretariat Komitetu Technicznego KT 222 i sekretariaty podkomitetów KT 222 prowadzi Instytut Nafty i Gazu - Państwowy Instytut Badawczy (INiG - PIB).

W skład organów technicznych (OT) PKN, którymi są komitety techniczne (KT) i podkomitety (PK), wchodzą specjaliści delegowani przez różne środowiska zainteresowane określonym zakresem tematycznym. Członkiem KT może zostać każdy podmiot zainteresowany normalizacją w danym obszarze tematycznym, zarejestrowany i prowadzący działalność gospodarczą na terenie Polski. Każdy członek może delegować do organu technicznego trzech reprezentantów. Komitety techniczne prowadzą prace normalizacyjne na poziomie krajowym, regionalnym, czyli w ramach Europejskiego Komitetu Normalizacyjnego (CEN), oraz międzynarodowym - w ramach Międzynarodowej Organizacji Normalizacyjnej (ISO) [4]. W tablicy 1 podano liczbę członków i reprezentantów w KT 222 i w podkomitetach KT 222.

Tablica 1. Liczba członków i reprezentantów w KT 222 i w podkomitetach KT 222 [4]

\begin{tabular}{|l|l|c|c|}
\hline \multicolumn{2}{|c|}{ Organ techniczny } & $\begin{array}{c}\text { Liczba } \\
\text { członków }\end{array}$ & $\begin{array}{c}\text { Liczba } \\
\text { reprezentantów }\end{array}$ \\
\hline KT 222 & $\begin{array}{l}\text { Przetworów Naftowych } \\
\text { i Cieczy Eksploatacyjnych }\end{array}$ & 28 & 43 \\
\hline KT 222/PK 1 & Paliw Płynnych & 21 & 33 \\
\hline KT 222/PK 2 & Asfaltów & 16 & 25 \\
\hline KT 222/PK 3 & Olejów Smarowych & 14 & 23 \\
\hline
\end{tabular}

\section{System informatyczny PZN (e-KT) - Polski Zasób Normalizacyjny}

Prezes PKN zarządzeniem nr 36 z dnia 28 września 2012 r. wprowadził w Polskim Komitecie Normalizacyjnym do wyłącznego stosowania w pracach organów technicznych PKN system informatyczny PZN (e-KT) [18]. System PZN (e-KT) - Polski Zasób Normalizacyjny jest systemem informatycznym - aplikacją webową (dostępną przez Internet), będącą bazą danych o Polskich Normach i dokumentach normalizacyjnych oraz organizacjach normalizacyjnych, służącą do kompleksowego zarządzania pracami normalizacyjnymi w PKN oraz udostępniającą organom technicznym (OT) funkcjonalności do zarządzania pracami w OT, z funkcją uwierzytelniania głosowania przy wykorzystaniu hasła otrzymywanego za pomocą SMS.
System PZN ma za zadanie wspierać pracę członków OT w trakcie procesu opracowywania norm, udostępniając zasoby normalizacyjne PKN oraz umożliwiając efektywną komunikację pomiędzy członkami OT oraz pomiędzy członkami OT a pracownikami PKN. Zapewnia kompleksowe zarządzanie pracami OT, głosowaniami i dokumentami w obiegu wewnętrznym OT. Umożliwia zarządzanie zasobami: dokumentami normalizacyjnymi, uprawnieniami użytkowników i ich rolami oraz pracami w OT. Gwarantuje szybki do nich dostęp, sprawną dystrybucję, zatwierdzanie, akceptowanie, tworzenie elektronicznych teczek akt normy oraz wykonywanie prac normalizacyjnych zgodnie z procedurami określonymi w PZN [4].

\section{Powołanie i umiejscowienie sekretariatów KT 222 i Podkomitetów KT 222/PK 1 ds. Paliw Płynnych, KT 222/PK 2 ds. Asfaltów, KT 222/PK 3 ds. Olejów Smarowych}

Prace podkomitetów działających w komitetach technicznych (w przypadku KT 222 były to podkomitety, wcześniej podkomisje, działające od 1994 roku) nie były ujęte bezpośrednio w procedurach PKN, lecz przebiegały według ustaleń wewnętrznych komitetów. Zmiany wprowadzone w procedurach PKN ujęły działalność podkomitetów jako organów technicznych (OT), przenosząc do podkomitetów większość zadań - zgodnie z uzgodnionym zakresem prac. W związku z tym należało przeprowadzić, zgodnie z nowymi procedurami, ustalenie zakresu działania, zgłoszenie udziału członków, powołanie, decyzję o lokalizacji sekretariatu. Członkowie (podmioty) zgodnie z nowymi zasadami zgłosili swój udział oraz reprezentantów do nowo powstających organów technicznych (OT). W Komitecie Technicznym 222 odbyły 
się głosowania - jednogłośnie powołano podkomitety o podanych wyżej zakresach działania (kwiecień 2014). Ponieważ PKN może powierzyć prowadzenie sekretariatu KT podmiotowi zewnętrznemu, w podkomitetach odbyły się wymagane procedurami głosowania dotyczące umiejscowienia sekretariatów podkomitetów (maj 2014) w dotychczasowej lokalizacji, czyli w Instytucie Nafty i Gazu - Państwowym Instytucie Badawczym (INiG - PIB). Głosowania zakończone zostały jednogłośną akceptacją uchwał o prowadzeniu sekretariatów podkomitetów przez INiG - PIB. Instytut, jako podmiot zewnętrzny prowadzący sekretariaty KT 222 i KT 222/PK, wyznaczył osoby spośród swoich pracowników do pełnienia funkcji sekretarzy. Pracownik PKN pełni funkcję konsultanta OT. Zadaniem konsultanta jest m.in. zapewnienie niezbędnej pomocy i wsparcia w przestrzeganiu przez KT (w tym PK) przepisów wewnętrznych PKN dotyczących działalności KT, w tym przepisów wewnętrznych CEN-CENELEC oraz procedur opracowywania norm i innych dokumentów normalizacyjnych, oraz nadzór nad prawidłowym przebiegiem realizowanych prac. Konsultantem KT 222 i jego trzech podkomitetów jest mgr inż. Magdalena Wienczatek.

\section{KT 222 ds. Przetworów Naftowych i Cieczy Eksploatacyjnych}

KT 222 - za pośrednictwem podkomitetów - opracowuje polskie wersje norm europejskich i norm międzynarodowych, opracowuje również PN własne, a także uczestniczy w procesie powstawania norm europejskich. Dążeniem KT 222 jest
Tablica 2. Liczba dokumentów normalizacyjnych opracowanych w Komitecie Technicznym 222 zatwierdzonych przez PKN w okresie styczeń 2014-wrzesień 2018 [4]

\begin{tabular}{|c|c|c|c|c|c|}
\hline 2014 & 2015 & 2016 & 2017 & 2018 & Razem \\
\hline 56 & 38 & 43 & 41 & 32 & 211 \\
\hline
\end{tabular}

uczestnictwo w pracach we wczesnych fazach opracowywania norm europejskich i norm międzynarodowych, które są istotne dla naszego kraju, poprzez delegowanie ekspertów do prac CEN i ISO [4]. W tablicy 2 podano liczbę dokumentów normalizacyjnych opracowanych w KT 222 zatwierdzonych przez PKN w okresie styczeń 2014-wrzesień 2018.

Z członkostwa w CEN krajowej jednostki normalizacyjnej w Polsce - PKN wynika obowiązek wprowadzenia do zbioru Polskich Norm: norm europejskich EN i EN-ISO jako PN-EN i PN-EN ISO w języku oryginału z przetłumaczonym na język polski tytułem i zakresem normy; jest to tzw. wersja angielska [16]. Natomiast opracowanie polskich wersji językowych norm europejskich PN-EN i PN-EN ISO, wprowadzenie do zbioru PN i opracowanie polskich wersji norm międzynarodowych PN-ISO, specyfikacji technicznych PKN-CEN/TS i PKN-ISO/TS, raportów technicznych PKN-CEN/TR oraz opracowanie norm własnych $\mathrm{PN}$ ( $\mathrm{PN}-\mathrm{C}$ w przypadku norm z zakresu sektora chemii) - czy to wprowadzających normy innych krajowych jednostek normalizacyjnych, czy opracowanych we własnym zakresie (np. z wyznaczeniem precyzji dla metody badań) - jest zależne od organu technicznego, w którego zakresie znajduje się tematyka dokumentu.

Tablica 3. Rodzaje dokumentów normalizacyjnych opracowywanych przez podkomitety KT 222

\begin{tabular}{|c|c|c|c|c|}
\hline \multicolumn{2}{|c|}{$\begin{array}{l}\text { Organizacje } \\
\text { normalizacyjne } \\
\text { - dokumenty }\end{array}$} & $\begin{array}{c}\text { Normy opublikowane } \\
\text { przez PKN } \\
\text { po ukazaniu się EN }\end{array}$ & $\begin{array}{l}\text { Dokumenty normalizacyjne opublikowane przez PKN } \\
\text { po opracowaniu przez komitet lub podkomitet } \\
- \text { w języku polskim }\end{array}$ & $\begin{array}{l}\text { Podkomitety KT } 222, \\
\text { które opracowują dany } \\
\text { rodzaj dokumentu }\end{array}$ \\
\hline \multirow{4}{*}{ CEN } & EN & $\begin{array}{l}\text { PN-EN }(\mathrm{E}) \\
\text { wersja angielska }\end{array}$ & PN-EN (P) wersja polska & PK 1, PK 2, PK 3 \\
\hline & EN ISO & $\begin{array}{l}\text { PN-EN ISO (E) } \\
\text { wersja angielska }\end{array}$ & PN-EN ISO (P) wersja polska & PK 1, PK 2, PK 3 \\
\hline & CEN/TR & - & PKN-CEN/TR & PK 1, PK 2, PK 3 \\
\hline & $\mathrm{CEN} / \mathrm{TS}$ & - & $\mathrm{PKN}-\mathrm{CEN} / \mathrm{TS}$ & PK 1, PK 2, PK 3 \\
\hline \multirow{2}{*}{ ISO } & ISO & - & PN-ISO & PK 1 , PK 3 \\
\hline & ISO/TS & - & $\mathrm{PKN}-\mathrm{ISO} / \mathrm{TS}$ & PK 1, PK 3 \\
\hline \multirow[t]{2}{*}{ PKN } & $\mathrm{PN}$ & - & $\begin{array}{l}\text { PN-C Polska Norma własna opracowana na podstawie } \\
\text { normy PN wycofanej lub jako nowelizacja PN-C }\end{array}$ & PK 1, PK 3 \\
\hline & PKN & - & PKN-C Polski Dokument Normalizacyjny & PK 1 \\
\hline DIN & DIN & - & $\begin{array}{l}\text { PN-C Polska Norma własna identyczna z normą } \\
\text { krajową DIN }\end{array}$ & PK 3 \\
\hline
\end{tabular}

* Niebieskim kolorem wyróżniono te dokumenty normalizacyjne - normy europejskie, których wersje krajowe w języku oryginału ukazują się w krajach członkowskich CEN w terminie do 6 miesięcy od opublikowania przez CEN.

${ }^{* *}$ Zielonym kolorem wyróżniono te dokumenty normalizacyjne - polskie wersje norm europejskich, wprowadzone metodą thumaczenia normy międzynarodowej, specyfikacje techniczne, raporty techniczne i normy własne oraz polski dokument normalizacyjny - przewodnik, które zostały opracowane z inicjatywy podkomitetów KT 222. 
Jeżeli dany temat znajdzie się w programie organu technicznego oraz ma źródło finansowania, można rozpocząć odpowiednią procedurę [1]. Opracowanie takich dokumentów normalizacyjnych z zakresu podkomitetów KT 222 jest możliwe dzięki finansowemu zaangażowaniu członków poszczególnych podkomitetów.

W tablicy 3 zestawiono rodzaje dokumentów normalizacyjnych opracowywanych przez podkomitety KT $222 \mathrm{w}$ odniesieniu do podstawowych dokumentów normalizacyjnych opracowywanych przez organizacje normalizacyjne: Europejski Komitet Normalizacyjny (CEN), Międzynarodową Organizacją Normalizacyjną (ISO), Polski Komitet Normalizacyjny (PKN) oraz krajową jednostkę normalizacyjną Niemiec Deutsches Institut für Normung (DIN). Niebieskim kolorem wyróżniono te dokumenty normalizacyjne - normy europejskie (EN), których wersje krajowe w języku oryginału ukazują się w krajach członkowskich CEN w terminie do 6 miesięcy od opublikowania przez CEN (w Polsce jako PN-EN lub
PN-EN ISO), co obligatoryjnie wynika z członkostwa w CEN. Zielonym kolorem wyróżniono te dokumenty normalizacyjne - opracowane w języku polskim normy europejskie, wprowadzone metodą tłumaczenia na język polski normy międzynarodowe, specyfikacje techniczne, raporty techniczne, normy własne oraz polski dokument normalizacyjny PKN-C, które zostały opracowane z inicjatywy podkomitetów. Opracowanie normy własnej (PN-C), która nie jest wprowadzeniem normy innej krajowej jednostki normalizacyjnej, ujmującej metodę badania, wymaga przeprowadzenia badań międzylaboratoryjnych w celu wyznaczenia precyzji metody. PKN zgodnie z rozporządzeniem Parlamentu Europejskiego i Rady (UE) nr 1025/2012 zamieszcza informacje o projektach Polskich Norm własnych i ich notyfikacji w CEN/CENELEC [4].

W tablicy 4 przedstawiono wykaz polskich dokumentów normalizacyjnych z zakresu KT 222 opublikowanych w latach 2007-2017 opracowanych przez podkomitety KT 222.

Tablica 4. Polskie dokumenty normalizacyjne z zakresu KT 222 opublikowane w latach 2007-2017 opracowane przez podkomitety KT 222

Dokument normalizacyjny

PKN-C-1:2011 wersja polska, Przewodnik do przeliczania gęstości biopaliw przeznaczonych do zasilania silników z zaptonem samoczynnym

PK 1

PKN-CEN/TR 14489:2014-04 wersja polska, Trudnopalne ciecze hydrauliczne - Klasyfikacja i wymagania - Wytyczne wyboru ze względu na bezpieczeństwo, ochronę zdrowia i środowiska naturalnego

PK 3

PKN-CEN/TR 15138:2009 wersja polska, Produkty naftowe i inne ciecze - Przewodnik oznaczania temperatury zaplonu

PKN-CEN/TR 15367-1:2007 wersja angielska, norma wycofana, Petroleum products - Guide for good housekeeping Part 1: Automotive diesel fuels

PKN-CEN/TR 15367-1:2009 wersja polska, norma wycofana, Przetwory naftowe - Poradnik prawidlowego postępowania-Część 1: Oleje napędowe

PKN-CEN/TR 15367-1:2016-04 wersja polska, Przetwory naftowe-Poradnik prawidłowego postępowania-Część 1: Oleje napędowe do pojazdów samochodowych

PKN-CEN/TR 15367-2:2007 wersja angielska, norma wycofana, Petroleum products - Guide for good housekeeping Part 2: Automotive petrol fuels

PKN-CEN/TR 15367-2:2009 wersja polska, Przetwory naftowe - Poradnik prawidłowego postępowania - Część 2: Benzyna samochodowa

PKN-CEN/TR 15367-3:2011 wersja polska, Przetwory naftowe - Poradnik prawidłowego postęowania - Część 3: Zabezpieczenie przed zanieczyszczeniem międzyproduktowym

PKN-CEN/TR 15738:2010 wersja polska, Przetwory naftowe - Oleje opałowe lekkie - Potrzeby, możliwości $i$ wymagane oczekiwania dla wspólnej europejskiej specyfikacji

PKN-CEN/TR 15745:2014-06 wersja polska, Ciekłe produkty naftowe-Oznaczanie typów węglowodorów oraz zwiazków tlenowych metodą wielowymiarowej chromatografii gazowej-Raport badawczy z badań międzylaboratoryjnych

PKN-CEN/TR 16227:2015-04 wersja polska, Ciekte przetwory naftowe-Biośrodki smarowe - Zalecenia dotyczace terminologii i charakterystyki biośrodków smarowych i biobazowych środków smarowych

PKN-CEN/TR 16435:2014-06 wersja polska, Ciekłe przetwory naftowe - Komponowanie zwiazków tlenowych zgodnie z aktualnymi wymaganiami EN 228

PKN-CEN/TS 15293:2012 wersja polska, norma wycofana, Paliwa do pojazdów samochodowych-Paliwo etanolowe (E85) do pojazdów samochodowych - Wymagania i metody badań

PKN-CEN/TS 15324:2010 wersja polska, Asfalty i lepiszcza asfaltowe-Oznaczanie temperatury lepkości równoważnej na podstawie pomiaru lepkości przy małej prędkości ścinania z zastosowaniem reometru dynamicznego ścinania w try- 


\section{cd. Tablica 4}

\begin{tabular}{|c|c|}
\hline Dokument normalizacyjny & Podkomitet \\
\hline $\begin{array}{l}\text { PKN-CEN/TS } 15325: 2010 \text { wersja polska, Asfalty i lepiszcza asfaltowe - Oznaczanie lepkości zerowego ścinania (ZSV) } \\
\text { metoda petzania w reometrze dynamicznego ścinania }\end{array}$ & PK 2 \\
\hline $\begin{array}{l}\text { PKN-CEN/TS 15963:2015-10 wersja polska, Asfalty i lepiszcza asfaltowe - Oznaczanie temperatury odporności na kru- } \\
\text { che pękanie próbki z karbem za pomoca badania metoda belki trzypunktowo zginanej }\end{array}$ & PK 2 \\
\hline $\begin{array}{l}\text { PKN-CEN/TS 16346:2016-04 wersja polska, Lepiszcza asfaltowe - Oznaczanie charakteru rozpadu oraz natychmiasto- } \\
\text { wej przyczepności kationowych emulsji asfaltowych do kruszywa 2/4 mm }\end{array}$ & PK 2 \\
\hline $\begin{array}{l}\text { PN-C-04062:2018-05 wersja polska, Przetwory naftowe - Oznaczanie ciepła spalania paliw ciektych w bombie kalory- } \\
\text { metrycznej i obliczanie wartości opałowej z zastosowaniem wzorów empirycznych }\end{array}$ & PK 1 \\
\hline $\begin{array}{l}\text { PN-C-04313:2018-02 wersja polska, Przetwory naftowe - Określanie penetracji parafin i cerezyn - Metoda z penetro- } \\
\text { metrem z igta }\end{array}$ & PK 3 \\
\hline PN-C-04314:2016-01 wersja polska, Ropa naftowa-Oznaczanie zawartości parafiny & PK 3 \\
\hline PN-C-04361:2017-02 wersja polska, Przetwory naftowe - Oznaczanie zawartości ciat stałych obcych - Metoda ekstrakcyjna & PK 3 \\
\hline PN-C-04362:2017-03 wersja polska, Przetwory naftowe - Badanie właściwości smarnych olejów i smarów & PK 3 \\
\hline $\begin{array}{l}\text { PN-C-96013:2014-03 wersja polska, Badanie smarów - Badanie zachowania się smarów plastycznych w obecności } \\
\text { wody-Badanie w warunkach statycznych; wprowadza: DIN 51807-1:1979-04 [IDT] }\end{array}$ & PK 3 \\
\hline $\begin{array}{l}\text { PN-C-96014:2014-05 wersja polska, Środki smarowe - Smary plastyczne klasy K- Klasyfikacja i wymagania; wprowa- } \\
\text { dza: DIN 51825:2004-06 [IDT] }\end{array}$ & PK 3 \\
\hline $\begin{array}{l}\text { PN-C-96015:2014-05 wersja polska, Środki smarowe - Smary plastyczne klasy G-Klasyfikacja i wymagania; wprowa- } \\
\text { dza: DIN 51826:2005-01 [IDT] }\end{array}$ & PK 3 \\
\hline $\begin{array}{l}\text { PN-C-96016:2014-05 wersja polska, Badanie środków smarowych - Oznaczanie wydzielania oleju ze smaru plastyczne- } \\
\text { go w warunkach statycznych; wprowadza: DIN 51817:1998-04 [IDT] }\end{array}$ & PK 3 \\
\hline $\begin{array}{l}\text { PN-C-96017:2015-10 wersja polska, Środki smarowe - Oleje smarowe VB bez dodatków i z dodatkami oraz oleje sma- } \\
\text { rowe VDL - Klasyfikacja i wymagania; wprowadza: DIN 51506:2013-12 [IDT] }\end{array}$ & PK 3 \\
\hline $\begin{array}{l}\text { PN-C-96031:2016-01 wersja polska, Oznaczanie zawartości ciat statych w smarach plastycznych (wielkość czastek po- } \\
\text { wyżej } 25 \mu \mathrm{m} \text { ); wprowadza: DIN 51813:1989-09 [IDT] }\end{array}$ & PK 3 \\
\hline PN-C-96050:2017-06 wersja polska, Przetwory naftowe-Oleje odpadowe do regeneracji & PK 1 \\
\hline
\end{tabular}

Przewodniczącym KT 222 jest mgr inż. Stefan Ptak, reprezentant INiG - PIB w KT 222 oraz wcześniej reprezentant INiG - PIB w Podkomitecie KT 222/PK 2 ds. Asfaltów i w Podkomitecie KT 222/PK 3 ds. Olejów Smarowych. W marcu 2018 roku kadencję przewodniczącego zakończył dr inż. Stanisław Oleksiak, reprezentant INiG - PIB, powołany w marcu 2014 roku, zastępujący wtedy dr. inż. Wiesława Górskiego - zasłużonego dla normalizacji specjalisty, pełniącego funkcję przewodniczącego KT 222 od czasu jego powstania w 1994 roku. Sekretarzem KT 222 jest mgr inż. Zofia Błaszkiewicz, wcześniej pełniąca funkcję sekretarza Podkomitetu ds. Paliw Płynnych. W tablicy 5 podano aktualną listę członków KT 222 ds. Przetworów Naftowych i Cieczy Eksploatacyjnych, dostępną na stronie internetowej PKN.

Dokumenty normalizacyjne opracowywane aktualnie w podkomitetach KT 222 obejmują przede wszystkim tematy wynikające z obowiązkowo przeprowadzanej procedury normalizacyjnej opracowania EN z uznaniem EN za PN (inaczej: wprowadzenie EN do zbioru Polskich Norm, jako PN-EN). Realizacja tej procedury polega kolejno na uzgodnieniu w OT wersji polskiej tytułu, zakresu normy i wskazaniu norm sprzecznych bezpośrednio po ukazaniu się projektu normy europej- skiej (EN). Następnie - na uczestnictwie w szczególnie istotnym etapie procedury, $\mathrm{tj}$. $\mathrm{w}$ ankiecie powszechnej (enquire) projektu pPN-prEN, kiedy możemy mieć wpływ na zapisy normy, obejmującym m.in. uzgodnienie w OT uwag krajowych do projektu - opiniowanie i głosowanie stanowiska krajowego oraz, jeżeli etap jest $w$ harmonogramie, udziale w głosowaniu formalnym (formal vote) [4]. Drugą grupę dokumentów stanowią dokumenty normalizacyjne w języku polskim, opracowywane z inicjatywy podkomitetów. Liczba aktualnych dokumentów normalizacyjnych w języku polskim jest różnicą pomiędzy liczbą wszystkich dokumentów normalizacyjnych w języku polskim, które zostały opublikowane, i liczbą dokumentów wycofanych ze względu na zastąpienie przez nowe wydanie lub ze względu na sprzeczność $\mathrm{z}$ wprowadzanymi normami europejskimi. W tablicy 6 podano liczbę dokumentów normalizacyjnych znajdujących się aktualnie w programach podkomitetów KT 222, liczbę wszystkich aktualnych, w wersji polskiej i w wersji angielskiej, polskich dokumentów normalizacyjnych oraz liczbę aktualnych dokumentów normalizacyjnych w języku polskim opracowanych przez podkomitety KT 222 [4].

Realizacja programów normalizacyjnych, w wyniku których opracowano wersje polskie dokumentów normalizacyjnych 
i normy własne, jest możliwa dzięki finansowemu zaangażowaniu członków podkomitetów reprezentujących przemysł rafineryjny.

Tablica 5. Lista członków KT 222 ds. Przetworów Naftowych i Cieczy Eksploatacyjnych [4]

\begin{tabular}{|c|l|}
\hline 1. & Agencja Rezerw Materiałowych \\
\hline 2. & Akwawit SA \\
\hline 3. & BP EUROPA SE Spółka Europejska Oddział w Polsce \\
\hline 4. & Centrum Badań i Dozoru Górnictwa Podziemnego Sp. z o.o. \\
\hline 5. & Grupa LOTOS SA \\
\hline 6. & Instytut Badań i Rozwoju Motoryzacji BOSMAL Sp. z o.o. \\
\hline 7. & Instytut Nafty i Gazu - Państwowy Instytut Badawczy \\
\hline 8. & Instytut Techniczny Wojsk Lotniczych \\
\hline 9. & Instytut Transportu Samochodowego \\
\hline 10. & LOTOS Asfalt Sp. z o.o. \\
\hline 11. & LOTOS Lab Sp. z o.o. \\
\hline 12. & LOTOS Paliwa Sp. z o.o. \\
\hline 13. & ORLEN Asfalt Sp. z o.o. \\
\hline 14. & ORLEN Laboratorium SA \\
\hline 15. & ORLEN OIL Sp. z o.o. \\
\hline 16. & ORLEN Południe SA \\
\hline 17. & Operator Logistyczny Paliw Płynnych Sp. z o.o. \\
\hline 18. & Polska Izba Paliw Płynnych \\
\hline 19. & Polska Organizacja Gazu Płynnego \\
\hline 20. & Polska Organizacja Przemysłu i Handlu Naftowego \\
\hline 21. & Polski Koncern Naftowy ORLEN SA \\
\hline 22. & Polskie Centrum Badań i Certyfikacji SA \\
\hline 23. & Polwax SA \\
\hline 24. & Przemysłowy Instytut Motoryzacji \\
\hline 25. & Stowarzyszenie Inżynierów i Techników Komunikacji \\
\hline 26. & Stowarzyszenie Krajowa Izba Biopaliw \\
\hline 27. & Warter Fuels SA \\
\hline 28. & Zakłady Chemiczne Organika SA \\
\hline
\end{tabular}

\section{Podkomitet KT 222/PK 1 ds. Paliw Plynnych}

W lipcu 2014 roku na przewodniczącego KT 222/PK 1 została powołana dr inż. Martynika Pałuchowska, reprezentant INiG - PIB, delegowana jako ekspert (w 2006 roku) do prac w grupie roboczej CEN/TC 19/WG 21 Specification for unleaded petrol. Dr inż. Martynika Pałuchowska zastąiła w pełnieniu tej funkcji wieloletniego przewodniczącego Podkomitetu Paliw Płynnych, a zarazem zastępcę przewodniczącego Komitetu Technicznego 222 dr. inż. Ludwika Kossowicza - nestora polskiego przemysłu naftowego, wybitnie zasłużonego dla normalizacji przetworów naftowych, a w szczególności dla normalizacji paliw płynnych. W 2018 roku, po upływie czteroletniej kadencji,
Tablica 6. Liczba dokumentów normalizacyjnych znajdujących się aktualnie w programach podkomitetów KT 222 i liczba wszystkich aktualnych dokumentów normalizacyjnych [4]

\begin{tabular}{|l|c|}
\hline $\begin{array}{l}\text { Liczba dokumentów normalizacyjnych } \\
\text { w programach podkomitetów KT 222 }\end{array}$ & 38 \\
\hline $\begin{array}{l}\text { Liczba wszystkich aktualnych dokumentów } \\
\text { normalizacyjnych }\end{array}$ & 250 \\
\hline $\begin{array}{l}\text { Liczba aktualnych dokumentów normalizacyjnych } \\
\text { w języku polskim }\end{array}$ & 144 \\
\hline
\end{tabular}

Tablica 7. Lista członków KT 222/PK 1 ds. Paliw Płynnych [4]

\begin{tabular}{|c|l|}
\hline 1. & Agencja Rezerw Materiałowych \\
\hline 2. & BP EUROPA SE Spółka Europejska Oddział w Polsce \\
\hline 3. & Grupa LOTOS SA \\
\hline 4. & Instytut Badań i Rozwoju Motoryzacji BOSMAL Sp. z o.o. \\
\hline 5. & Instytut Nafty i Gazu - Państwowy Instytut Badawczy \\
\hline 6. & Instytut Techniczny Wojsk Lotniczych \\
\hline 7. & Instytut Transportu Samochodowego \\
\hline 8. & LOTOS Lab Sp. z o.o. \\
\hline 9. & LOTOS Paliwa Sp. z o.o. \\
\hline 10. & ONICO SA \\
\hline 11. & ORLEN Laboratorium SA \\
\hline 12. & ORLEN Paliwa Sp. z o.o. \\
\hline 13. & ORLEN Południe SA \\
\hline 14. & Operator Logistyczny Paliw Płynnych Sp. z o.o. \\
\hline 15. & Polska Izba Paliw Płynnych \\
\hline 16. & Polska Organizacja Przemysłu i Handlu Naftowego \\
\hline 17. & Polski Koncern Naftowy ORLEN SA \\
\hline 18. & Polwax SA \\
\hline 19. & Przemysłowy Instytut Motoryzacji \\
\hline 20. & Shell Polska Sp. z o.o. \\
\hline 21. & Warter Fuels SA \\
\hline
\end{tabular}

dr inż. Martynika Pałuchowska została ponownie wybrana na kolejną kadencję. Sekretarzem KT 222/PK 1 jest lic. Iwona Doening. W tablicy 7 podano aktualną listę członków KT 222/ PK 1 ds. Paliw Płynnych, dostępną na stronie internetowej PKN.

Coroczny program prac podkomitetu obejmuje zadania wynikające z członkostwa w CEN i ISO oraz opracowanie polskich wersji norm paliwowych na metody badań i produkty, włączając w to m.in. uzgodnienie załączników krajowych do aktualizowanych norm produktowych na paliwa, takich jak: PN-EN 228+A1:2017-06 wersja polska, Paliwa do pojazdów samochodowych - Benzyna bezolowiowa - Wymagania i metody badań [8], PN-EN 590+A1:2017-06 wersja polska, Paliwa do pojazdów samochodowych - Oleje napędowe - Wymagania i metody badań [10], PN-EN 589+A1:2012 wersja polska, Paliwa do pojazdów samochodowych - LPG - Wymagania i metody badań [9], PN-EN 14214+A1:2014-04 wersja polska, Ciekle 
przetwory naftowe - Estry metylowe kwasów tłuszczowych (FAME) do uzytku w silnikach samochodowych o zapłonie samoczynnym (Diesla) i zastosowań grzewczych - Wymagania $i$ metody badań [11]. Normy na produkty są podstawą do aktualizacji rozporządzeń właściwego ministra dotyczących wymagań odnośnie do jakości paliw [17] i biopaliw [7]. Normy na metody badań powoływane są w rozporządzeniach właściwego ministra dotyczących badania jakości paliw i biopaliw [6].

Od czterech lat coroczny program prac podkomitetu obejmuje również informację o pracach grup roboczych zajmujących się najistotniejszymi zagadnieniami w obszarze normalizacji paliw płynnych: CEN/TC 19/WG 21 Specification for unleaded petrol, CEN/TC 19/WG 23 Specification of automotive LPG and related test method, CEN/TC 19/WG 24 Specification of distillate fuels, CEN/TC 19/WG 9 Chromatographic test method [2]. Posiedzenia grup roboczych WG odbywają się przeważnie dwa razy w roku. Dokumenty WG nie są udostępniane bezpośrednio w aplikacji PZN/KT 222/PK 1 dla logujących się w systemie reprezentantów tak jak dokumenty komitetów technicznych (CEN/TC 19_N...). Wynika to z przepisów wewnętrznych CEN oraz ISO dotyczących podziału prac i zadań między WG a TC, zgodnie z którymi dokumenty WG nie mogą być udostępniane reprezentantom KT czy PK, jako dokumenty prawnie chronione. Natomiast eksperci uczestniczący w pracach WG mają obowiązek przekazywania sprawozdań odpowiednio do KT lub do PK z prac prowadzonych w WG [4]. Na posiedzeniach podkomitetu specjaliści INiG - PIB, delegowani do CEN/TC 19/WG jako eksperci, przedstawiają informacje dotyczące aktualnych prac grup roboczych WG odnośnie do tematyki planowanej na najbliższe posiedzenie lub - po posiedzeniu - przekazują informacje o ustaleniach podjętych w grupach roboczych. Odpowiednio tematykę poszczególnych grup roboczych referują: WG 21 - dr inż. Martynika Pałuchowska, WG 23 - mgr inż. Delfina Rogowska, WG 24 - dr inż. Jan Lubowicz i dr inż. Magdalena Żółty, WG 9 - mgr inż. Zygmunt Burnus. Uczestnictwo w pracach grup roboczych WG daje realne szanse wpływu na istotne postanowienia zawarte w normach, gdyż to te grupy są organami opracowującymi projekty norm europejskich. Uzgodnienie najistotniejszych zapisów odbywa się w trakcie pracy WG nad projektem, zaś komitety techniczne CEN/TC opiniują i akceptują/zatwierdzają projekty na poszczególnych etapach. W taki sposób w wyniku zgłoszenia na forum WG 21 przez ekspertów z Polski propozycji włączenia zapisu o możliwości stosowania komponentów ze źródeł odnawialnych w 2017 roku w EN 228 wprowadzono punkt 5.1.2. Inne biokomponenty, pozwalający na komponowanie benzyny $\mathrm{z}$,węglowodorami syntetycznymi oraz innymi odnawialnymi węglowodorami” [8]. Sprzeciw wobec propozycji zapisu w projekcie normy wymaga merytorycznej argumentacji popartej materiałem badawczym [3]. Natomiast ankieta powszechna (enquiry) projektu pozwala wszystkim krajowym jednostkom normalizacyjnym (KJN) na zgłaszanie uwag: ogólnych, technicznych, edytorskich, które mogą, lecz nie muszą, zostać zaakceptowane. W ten sposób propozycja rozszerzenia definicji LPG w EN 589, zgłoszona w ankiecie powszechnej przez OT - KT 222/PK 1 za pośrednictwem polskiej KJN, która jest PKN, pozwalająca na wykorzystanie propanu i butanu pochodzących z różnych źródeł, w tym biologicznego, została zaakceptowana i wprowadzona do FprEN 589 [15]. W tablicy 8 podano liczbę dokumentów normalizacyjnych znajdujących się aktualnie w programie KT 222/PK 1, liczbę wszystkich aktualnych, w wersji polskiej i w wersji angielskiej, polskich dokumentów normalizacyjnych oraz liczbę aktualnych dokumentów normalizacyjnych w języku polskim [4].

Tablica 8. Liczba dokumentów normalizacyjnych w programie KT 222/PK 1 i liczba aktualnych dokumentów normalizacyjnych [4]

\begin{tabular}{|l|c|}
\hline $\begin{array}{l}\text { Liczba dokumentów normalizacyjnych } \\
\text { w programie }\end{array}$ & 22 \\
\hline $\begin{array}{l}\text { Liczba wszystkich aktualnych dokumentów } \\
\text { normalizacyjnych }\end{array}$ & 111 \\
\hline $\begin{array}{l}\text { Liczba aktualnych dokumentów normalizacyjnych } \\
\text { w języku polskim }\end{array}$ & 54 \\
\hline
\end{tabular}

\section{Podkomitet KT 222/PK 2 ds. Asfaltów}

W Podkomitecie KT 222/PK 2 ds. Asfaltów funkcję przewodniczącego od 2006 roku do 2018 roku pełnił mgr inż. Andrzej Zdzienicki, reprezentujący ORLEN Asfalt Sp. z o.o. Po zakończeniu jego kolejnej kadencji do pełnienia funkcji przewodniczącego został wybrany, w sierpniu 2018 roku,

Tablica 9. Lista członków KT 222/PK 2 ds. Asfaltów [3]

\begin{tabular}{|c|l|}
\hline 1. & Generalna Dyrekcja Dróg Krajowych i Autostrad \\
\hline 2. & Grupa LOTOS SA \\
\hline 3. & Instytut Badawczy Dróg i Mostów \\
\hline 4. & Instytut Nafty i Gazu - Państwowy Instytut Badawczy \\
\hline 5. & LOTOS Asfalt Sp. z o.o. \\
\hline 6. & LOTOS Lab Sp. z o.o. \\
\hline 7. & NYNAS Sp. z o.o. \\
\hline 8. & ORLEN Asfalt Sp. z o.o. \\
\hline 9. & ORLEN Laboratorium SA \\
\hline 10. & ORLEN Południe SA \\
\hline 11. & Politechnika Warszawska \\
\hline 12. & Polski Koncern Naftowy ORLEN SA \\
\hline 13. & Polskie Centrum Badań i Certyfikacji SA \\
\hline 14. & Polwax SA \\
\hline 15. & TPA Sp. z o.o. \\
\hline 16. & Total Polska Sp. z o.o. \\
\hline
\end{tabular}


dr inż. Krzysztof Błażejowski - reprezentant ORLEN Asfalt Sekretarzem podkomitetu jest mgr inż. Elżbieta Trzaska. W tablicy 9 podano aktualną listę członków KT 222/PK 2 ds. Asfaltów, dostępną na stronie internetowej PKN.

W tablicy 10 podano liczbę dokumentów normalizacyjnych w programie KT 222/PK 2, liczbę wszystkich aktualnych, w wersji polskiej i w wersji angielskiej, polskich dokumentów normalizacyjnych oraz liczbę aktualnych dokumentów normalizacyjnych w języku polskim.

Tablica 10. Liczba dokumentów normalizacyjnych w programie KT 222/PK 2 i liczba aktualnych dokumentów normalizacyjnych [4]

\begin{tabular}{|l|c|}
\hline $\begin{array}{l}\text { Liczba dokumentów normalizacyjnych } \\
\text { w programie }\end{array}$ & 6 \\
\hline $\begin{array}{l}\text { Liczba wszystkich aktualnych } \\
\text { dokumentów normalizacyjnych }\end{array}$ & 57 \\
\hline $\begin{array}{l}\text { Liczba aktualnych dokumentów } \\
\text { normalizacyjnych w języku polskim }\end{array}$ & 25 \\
\hline
\end{tabular}

\section{KT 222/PK 3 ds. Olejów Smarowych}

W KT 222/PK 3 ds. Olejów Smarowych funkcję przewodniczącego pełni powołany w lutym 2018 roku mgr inż. Janusz Fudała, reprezentujący ORLEN Oil, który zastąpił mgr. inż. Jerzego Franka, reprezentującego tę samą firmę. W sierpniu bieżącego roku do pełnienia funkcji zastępcy przewodniczącego KT 222/PK 3 został powołany mgr inż. Henryk Szmyd, reprezentujący Grupę LOTOS. Sekretarzem KT 222/PK 3 jest mgr Joanna Moskała. W tablicy 11 podano aktualną listę członków KT 222/PK 3 ds. Olejów Smarowych, dostępną na stronie internetowej PKN. W tablicy 12 podano liczbę dokumentów normalizacyjnych w programie

Tablica 11. Lista członków KT 222/PK 3 ds. Olejów Smarowych [4]

\begin{tabular}{|c|l|}
\hline 1. & Boccard Polska Sp. z o.o. \\
\hline 2. & Grupa LOTOS SA \\
\hline 3. & Instytut Badań i Rozwoju Motoryzacji BOSMAL Sp. z o.o. \\
\hline 4. & Instytut Nafty i Gazu - Państwowy Instytut Badawczy \\
\hline 5. & Instytut Techniczny Wojsk Lotniczych \\
\hline 6. & Instytut Transportu Samochodowego \\
\hline 7. & LOTOS Lab Sp. z o.o. \\
\hline 8. & LOTOS Oil Sp. z o.o. \\
\hline 9. & ORLEN Laboratorium SA \\
\hline 10. & ORLEN OIL Sp. z o.o. \\
\hline 11. & Polska Organizacja Przemysłu i Handlu Naftowego \\
\hline 12. & Polskie Centrum Badań i Certyfikacji SA \\
\hline 13. & Polwax SA \\
\hline 14. & Przemysłowy Instytut Motoryzacji \\
\hline
\end{tabular}

KT 222/PK 3 liczbę wszystkich aktualnych, w wersji polskiej i w wersji angielskiej, polskich dokumentów normalizacyjnych oraz liczbę aktualnych dokumentów normalizacyjnych w języku polskim.

Tablica 12. Liczba dokumentów normalizacyjnych w programie KT 222/PK 3 i liczba aktualnych norm [4]

\begin{tabular}{|l|c|}
\hline $\begin{array}{l}\text { Liczba dokumentów normalizacyjnych } \\
\text { w programie podkomitetu }\end{array}$ & 10 \\
\hline $\begin{array}{l}\text { Liczba wszystkich aktualnych } \\
\text { dokumentów normalizacyjnych }\end{array}$ & 82 \\
\hline $\begin{array}{l}\text { Liczba aktualnych dokumentów } \\
\text { normalizacyjnych w języku polskim }\end{array}$ & 65 \\
\hline
\end{tabular}

\section{KT 144 ds. Koksu i Przetworzonych Paliw Stalych, odpowiadajacy CEN/TC 383 Sustainably produced biomass for energy applications}

Tematyka komitetu CEN/TC 383 Sustainably produced biomass for energy applications jest zlokalizowana w PKN w KT 144 ds. Koksu i Przetworzonych Paliw Stałych, którego zakres tematyczny obejmuje zagadnienia ogólne (klasyfikacja, terminologia, pobieranie próbek itp.), wymagania, metody badań własności mechanicznych, fizykochemicznych i chemicznych dotyczące koksu, półkoksu, paliw formowanych, brykietów, biopaliw stałych [4]. Normy z grupy EN 16214 Sustainability criteria for the production of biofuels and bioliquids for energy applications - Principles, criteria, indicators and verifiers znajdujące się w zakresie tematycznym KT 144 odnoszą się również do biopaliw ciekłych. INiG - PIB jest członkiem KT 144 ds. Koksu i Przetworzonych Paliw Stałych, a ekspertem INiG - PIB delegowanym do KT 144 i do grupy roboczej CEN/TC 383/WG 3 Biodiversity and environmental aspects jest mgr inż. Delfina Rogowska. Prace w obszarze zrównoważonego rozwoju są intensywnie kontynuowane [5], co generuje potrzebę nowelizacji znajdujących się w zakresie działania CEN/TC 383 wszystkich norm z grupy EN 16214 Sustainability criteria for the production of biofuels and bioliquids for energy applications - Principles, criteria, indicators and verifiers. W ciągu ostatnich trzech lat ukazały się w angielskiej wersji językowej trzy polskie normy - części PN-EN 16214 [12, 13, 14].

\section{KT 319 ds. Produktów Biobazowych, odpowiadający CEN/TC 411 Bio-based products}

W zakresie tematycznym KT 319 ds. Produktów Biobazowych znajdują się normy dotyczące terminologii, wymagań, metod badań, pobierania i przygotowywania próbek, kryteriów zrównoważonego rozwoju produktów biobazowych. INiG - PIB jest członkiem KT 319. W latach 2014-2018 ukazało się dziewięć polskich norm wprowadzających w języku oryginału normy europejskie z zakresu KT 319. 


\section{Popularyzacja działalności normalizacyjnej obszaru KT 222}

W celu spopularyzowania działalności normalizacyjnej obszaru KT 222 w środowisku zainteresowanym przetworami naftowymi zagadnienia te pojawiają się cyklicznie w tematyce konferencji organizowanych przez INiG - PIB. Podczas kolejnych edycji Konferencji Naukowo-Technicznej FUELS' ZOOM tematykę normalizacyjną związaną z paliwami płynnymi i biopaliwami przedstawiały przewodnicząca KT 222/ PK 1, a zarazem ekspert CEN/TC 19/WG 21 dr inż. Martynika Pałuchowska i sekretarz KT 222 mgr inż. Zofia Błaszkiewicz. Na Międzynarodowej Konferencji Naukowo-Technicznej ŚRODKI SMAROWE w kolejnych latach aspekty normalizacyjne środków smarowych były tematem referatów sekretarza KT 222 i sekretarza KT 222/PK 3 mgr Joanny Moskały. Tematyka ta została również omówiona w referacie sekretarza KT 222 i sekretarza KT 222/PK 3 podczas I Sympozjum LOTOS Oil ,Środki smarowe i płyny eksploatacyjne w Polsce 2017”. Sekretarz KT 222 prezentowała również referat dotyczący zagadnień normalizacyjnych w odniesieniu do paliw etanolowych dla transportu podczas Międzynarodowej Konferencji BIOTRETH „Paliwa alkoholowe dla transportu - uwarunkowania, badania i rozwój”, informacje oraz referaty dotyczące ogólnych zagadnień normalizacji na Konferencji Naukowo Technicznej XI Forum Dyskusyjne Sekcji PETROL-GAZ w Zamościu oraz podczas XI Forum Dyskusyjnego nt. „Analityczno-technologicznych aspektów jakości współczesnych przetworów naftowych, gazowych i biopaliw" we Włocławku.

Zagadnienia normalizacyjne ogólne, a zarazem dotyczące przetworów naftowych były wielokrotnie prezentowane przez przewodniczącą KT 222/PK 1 dr inż. Martynikę Pałuchowską, sekretarza KT 222 mgr inż. Zofię Błaszkiewicz, sekretarza KT 222/PK 1 lic. Iwonę Doening i sekretarza KT 222/PK 3 mgr Joannę Moskałę podczas szkoleń organizowanych przez INiG - PIB dla studentów odbywających praktyki w Instytucie oraz w ramach innych szkoleń, w których zajęcia prowadzili specjaliści Instytutu.

\section{Podsumowanie}

Normalizacja przetworów naftowych w Polsce realizowana jest przez podkomitety KT 222 - odpowiednio: KT 222/PK 1 ds. Paliw Płynnych, obejmujący paliwa płynne pochodzenia naftowego, produkty podobne pochodzenia syntetycznego i biologicznego, KT 222/PK 2 ds. Asfaltów - asfalty drogowe, asfalty przemysłowe, emulsje asfaltowe, KT 222/PK 3 ds. Olejów Smarowych - oleje smarowe i specjalne środki smarowe pochodzenia naftowego, produkty podobne pochodzenia syntetycznego i biologicznego. Przynależność polskiej krajowej jednostki normalizacyjnej - Polskiego Komitetu Normalizacyjnego do organizacji normalizacyjnych, międzynarodowej ISO i europejskiej CEN, wyznacza odpowiednie zadania do wykonania. Sekretariaty Komitetu Technicznego 222 i jego podkomitetów prowadzi Instytut Nafty i Gazu - Państwowy Instytut Badawczy. Rezultat prac normalizacyjnych obrazuje liczba opracowanych przez podkomitety KT 222 dokumentów normalizacyjnych, które ukazały się w ciągu ostatnich niespełna pięciu lat - przeszło 200 dokumentów, z których połowę stanowią dokumenty normalizacyjne w języku polskim. Taki rezultat jest możliwy do uzyskania przede wszystkim dzięki stałemu zaangażowaniu w prace normalizacyjne podmiotów z obszaru przemysłu rafineryjnego oraz wieloletniej, bardzo dobrej współpracy Instytutu i Polskiego Komitetu Normalizacyjnego, a także dzięki wspólnemu poszukiwaniu nowych rozwiązań wobec ciągle zmieniających się problemów, jakie napotyka realizacja zadań normalizacyjnych przez wszystkich zaangażowanych w działalność normalizacyjną.

Prosimy cytować jako: Nafta-Gaz 2018, nr 11, s. 846-855, DOI: 10.18668/NG.2018.11.09

Artykuł nadesłano do Redakcji 10.10.2018 r. Zatwierdzono do druku 7.12.2018 r.

\section{Literatura}

[1] Błaszkiewicz Z., Moskała J.: Normalizacja środków smarowych w Polsce. Nafta-Gaz 2017, nr 12, s. 980-987, DOI: 10.18668/ NG.2017.12.10.

[2] European Committee for Standardization, https://www.cen.eu (dostęp: wrzesień 2018).

[3] Informacje własne z prac CEN/TC 19 (dostęp: wrzesień 2018).

[4] Polski Komitet Normalizacyjny, http://www.pkn.pl (dostęp: wrzesień 2018).

[5] Rogowska D.: Renewable materials as feedstock for ener- gy production and other application. Nafta-Gaz 2017, nr 10, s. 793-798, DOI: 10.18668/NG.2017.10.09.

\section{Akty prawne i normatywne}

[6] Obwieszczenie Ministra Energii z dnia 18 stycznia 2017 r. w sprawie ogłoszenia jednolitego tekstu rozporządzenia Ministra Gospodarki w sprawie metod badania jakości paliw ciekłych, Dz.U. z 2017 r. poz. 247.

[7] Obwieszczenie Ministra Energii z dnia 10 lutego 2017 r. w sprawie 
ogłoszenia jednolitego tekstu rozporządzenia Ministra Gospodarki w sprawie wymagań jakościowych dla biokomponentów, metod badań jakości biokomponentów oraz sposobu pobierania próbek biokomponentów, Dz.U. z 2017 r. poz. 506.

[8] PN-EN 228+A1:2017-06 wersja polska, Paliwa do pojazdów samochodowych - Benzyna bezołowiowa - Wymagania i metody badań.

[9] PN-EN 589+A1:2012 wersja polska, Paliwa do pojazdów samochodowych - LPG - Wymagania i metody badań.

[10] PN-EN 590+A1:2017-06 wersja polska, Paliwa do pojazdów samochodowych - Oleje napędowe - Wymagania i metody badań.

[11] PN-EN 14214+A1:2014-04 wersja polska, Ciekte przetwory naftowe - Estry metylowe kwasów tluszczowych (FAME) do użyt$k u$ w silnikach samochodowych o zapłonie samoczynnym (Diesla) i zastosowań grzewczych - Wymagania i metody badań.

[12] PN-EN 16214-1:2013-02 wersja angielska, Kryteria zrównoważonego wykorzystania biopaliw i bioptynów do produkcji energii-Zasady, kryteria, wskaźniki i weryfikatory-Część 1: Terminologia.

[13] PN-EN 16214-3+A1:2017-09 wersja angielska, Kryteria zrównoważonego wykorzystania biopaliw i bioptynów do produkcji energii-Zasady, kryteria, wskaźniki i weryfikatory-Część 3: Bioróżnorodność $i$ aspekty środowiskowe $w$ odniesieniu do aspektów ochrony środowiska naturalnego.

[14] PN-EN 16214-4:2013-06 wersja angielska, Kryteria zrówno-

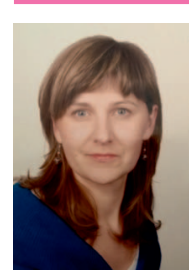

Lic. Iwona DOENING

Kierownik Działu Normalizacji

Instytut Nafty i Gazu - Państwowy Instytut Badawczy

ul. Lubicz 25 A

31-503 Kraków

e-mail: iwona.doening@inig.pl ważonego wykorzystania biopaliw i bioptynów do produkcji energii-Zasady, kryteria, wskaźniki i weryfikatory-Część 4: Metody obliczeniowe bilansu emisji gazów cieplarnianych za pomoca analizy cyklu życia.

[15] FGprPN-prEN 589E Automotive fuels - LPG-Requirements and test methods.

[16] Przepisy wewnętrzne CEN/CENELEC, Część 2, Wspólne reguły prac normalizacyjnych, grudzień 2014, www.pkn.pl (dostęp: wrzesień 2018).

[17] Rozporządzenie Ministra Gospodarki z dnia 9 października 2015 r. w sprawie wymagań jakościowych dla paliw ciekłych, Dz.U. z 2015 r. poz. 1680.

[18] Zarządzenie nr 36 Prezesa Polskiego Komitetu Normalizacyjnego z dnia 28 września 2012 r. w sprawie wprowadzenia do stosowania systemu PZN (e-KT) w pracach Organów Technicznych.

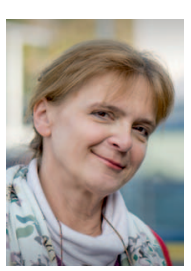

Mgr inż. Zofia BŁASZKIEWICZ

Starszy specjalista badawczo-techniczny;

kierownik Zakładu Normalizacji

Instytut Nafty i Gazu - Państwowy Instytut Badawczy

ul. Lubicz $25 \mathrm{~A}$

31-503 Kraków

E-mail: zofia.blaszkiewicz@inig.pl

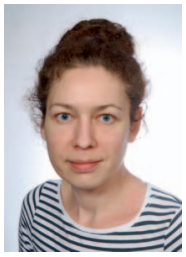

Mgr Joanna MOSKAŁA

Starszy specjalista inżynieryjno-techniczny w Zakładzie Normalizacji

Instytut Nafty i Gazu - Państwowy Instytut Badawczy ul. Lubicz $25 \mathrm{~A}$

31-503 Kraków

E-mail: jaonna.moskala@inig.pl

\section{OFERTA}

\section{ZAKŁAD NORMALIZACJI}

Zakres działania:

- prowadzenie Sekretariatu Komitetu Technicznego 222 ds. Przetworów Naftowych i Cieczy Eksploatacyjnych:

- $\quad$ prowadzenie Sekretariatu Podkomitetu ds. Paliw Płynnych KT222/PK1;

- $\quad$ prowadzenie Sekretariatu Podkomitetu ds. Asfaltów KT222/PK2 we współpracy z Zakładem Olejów, Środków Smarowych i Asfaltów;

- $\quad$ prowadzenie Sekretariatu Podkomitetu ds. Olejów Smarowych KT222/PK3;

» opracowywanie Polskich Norm PN, wprowadzających Normy Europejskie (EN) oraz Normy Międzynarodowe (ISO) z zakresu wymagań i metod badań: paliw silnikowych (benzyny silnikowej, olejów napędowych, LPG), biopaliw, biokomponentów, środków smarowychi asfaltów;

» opracowywanie Polskich Norm własnych z zakresu KT 222;

» opiniowanie dokumentów normalizacyjnych PKN, ISO i CEN z tego zakresu oraz udział w pracach normalizacyjnych Komitetów Technicznych CEN.

- opracowywanie Norm Zakładowych z dziedziny sektora naftowego i gazowniczego oraz prowadzenie rejestru i zbioru Norm Zakładowych INiG-PIB.

Dział ds. Sekretariatów Komitetów Technicznych nr 31 i nr 277 prowadzi Sekretariaty KT 31 i KT 277 